\title{
THE SECURITIES AND EXCHANGE COMMISSION AND ACCOUNTING PRINCIPLES
}

\author{
J. Arnold Pines*
}

I

The Commssion's Statutory Authoruty

The four principal statutes administered by the Securities and Exchange Commission $^{1}$ provide that registration statements, periodic reports, and applications or declarations for approval or effectiveness of proposed transactions, required to be filed with the Commission, shall contain financial statements that fully and fairly disclose the financial position and the earnings history of the registrant, applicant, or declarant, as the case may be.

Between 1920 and I933, approximately fifty billion dollars of new securities issues were sold to American investors. In a majority of cases, public purchasers were not furnished information that was adequate as a basis for an informed investment decision. By 1933 , about half of the securities newly issued since I920, or some twentyfive billion dollars' worth, had become worthless. ${ }^{2}$ 'The Securities Act of 1933 was designed not only to prevent fraud in the sale of securities and to provide investors with adequate information but also to protect legitimate enterprises seeking to obtain capital honestly through factual disclosure against dishonest competition. The act requires the inclusion in prospectuses of balance sheets and profit and loss statements "in such form as the Commission shall prescribe" and authorizes the Commission to prescribe, among other things, "the items or details to be shown in the balance sheet and earning statement, and the methods to be followed in the preparation of accounts." The Securities Exchange Act of 1934 confers similar authority on the Commission. The Investment Company Act of $1940^{6}$ and the Public Utility Holding Company Act of $1935^{7}$ confer on the Commission an even broader power with respect to financial reporting.

* B.S. I939, Rutgers University School of Business Adminisţration; Certified Public Accountant, New Jersey; Associate Director, Division of Corporate Regulation, Securities and Exchange Commission.

The Securities and Exchange Commission, as a matter of policy, disclaims responsibility for any private publication by any of its employees. The views expressed herein are those of the author and do not necessarily reflect the views of the Commission or of the author's colleagues on the staff of the Commission.

${ }^{1}$ Securities Act of 1933, 48 Stat. 74, as amended, I5 U.S.C. $\$ 77 \mathrm{a}$-aa (1964); Securities Exchange Act of 1934,48 Stat. $88 \mathrm{r}$, as amended, 15 U.S.C. $\$ \$ 7 \mathrm{a}-\mathrm{hh}$ (1964); Public Utility Holding Company Act of 1935, 49 Stat. 803 , as amended, I5 U.S.C. $\$ \$ 79$ to $z-6$ (xg64); Investment Company Act of 1940, 54 Stat. 789 , as amended, I5 U.S.C. $\$ \$ 80 \mathrm{a}-\mathrm{I}$ to a-52 (1964).

2 IO SEC ANN. REP. I3-I 4 (I944).

${ }^{3}$ Schedule A, II (25)-(26), 48 Stat. 90, I5 U.S.C. $\$ 77 a a(25)-(26)(1964)$.

- $\$ 9$ (a), 48 Stat. 85, as amended, I5 U.S.C. $\$ 77$ s(a) (I964).

${ }^{\circ} \S \mathrm{I}_{3}(\mathrm{~b}), 48$ Stat. $894, x_{5}$ U.S.C. $\$ 78 \mathrm{~m}(\mathrm{~b})\left(x_{964}\right)$.

o $\$ \$ 30-3 I, 54$ Stat. 836 , I5 U.S.C. $\$ \$ 80 a-29$ to 30 (1964).

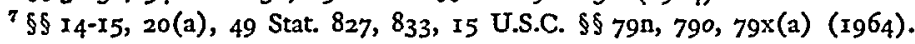


The Securities Act also provides that the financial statements required to be made available to the public through filing with the Commission shall be certified by "an independent public or certified accountant." The other three statutes permit the Commission to require that such statements be accompanied by a certificate of an independent public accountant, ${ }^{0}$ and the Commission's rules now require, with certain exceptions, that they be so certified.

Section 8(d) of the Securities Act ${ }^{10}$ provides that, if it appears to the Commission at any time that a registration statement contains an untrue statement of a material fact or omits to state any material fact required to be stated therein or necessary to make the statements therein not misleading, the Commission may institute proceedings looking to the issuance of a stop order suspending the effectiveness of the registration statement. Where such an order is issued, the offering cannot lawfully be made, or continued if it has already begun, until the registration statement has been amended to cure the deficiencies and the Commission has lifted the stop order. Section I9(a) (2) of the Securities Exchange Act authorizes the Commission "to suspend for a period not exceeding twelve months, or to withdraw, the registration of a security" if, in its opinion, such action is necessary or appropriate for the protection of investors and if the Commission "finds that the issuer of such security has failed to comply" with any provision of the statute "or the rules and regulations thereunder." $" 11$

The Commission has prescribed uniform systems of accounts for companies subject to the Holding Company Act; ${ }^{12}$ has promulgated rules under the Securities Exchange Act with respect to accounting and auditing of securities brokers and dealers; $;^{13}$ has adopted rules under the Investment Company Act governing the records to be maintained by registered investment companies, certain majority-owned subsidiaries thereof, and other persons having transactions with registered investment companies; ${ }^{14}$ has prescribed a rule under the Investment Advisers Act of

\footnotetext{
${ }^{8}$ Schedule A, If (25)-(26), 48 Stat. 90 (1933), 15 U.S.C. $\$ 77 a a(25)-(26)$ (1964).

${ }^{2}$ Securities Exchange Act of $1934, \$ \mathrm{I}_{3}$ (a)(2), 78 Stat. 569 (1964), 15 U.S.C. $\$ 78 \mathrm{~m}$ (a) (2) (1964); Public Utility Holding Company Act of $1935, \S 14,49$ Stat. 827, 15 U.S.C. $\$ 79 n$ (1964); Investment Company Act of $1940, \S 30(e), 54$ Stat. 836 , 15 U.S.C. $\$ 80 a-29$ (e) (1964).

${ }^{10}{ }_{48}$ Stat. 79 (1933), 15 U.S.C. $\$ 77$ h(d) (1964).

${ }^{12} \S 19(\mathrm{a})(2), 48$ Stat. 898 (1934), 15 U.S.C. $\$ 78 \mathrm{~s}(\mathrm{a})(2)(1964)$. See also $\$ 19(\mathrm{a})(4)$ of the Securities Exchange Act, 48 Stat. 898 (1934), 15 U.S.C. $\$ 78 \mathrm{~s}(\mathrm{a})$ (4) (1964), which authorizes the Commission "if in its opinion the public interest so requires, summarily to suspend trading in any registered security on any national securities exchange for a period not exceeding ten days ..." and $\$ 15(c)(5)$ of the same act, 78 Stat. 573 ( 1964$)$, I5 U.S.C. $\$ 780(\mathrm{c})(5)(1964)$, for a generally similar provision respecting the suspension of trading in any security otherwise than on a national securities exchange.

${ }_{12}$ Uniform System of Accounts for Mutual Service Companies and Subsidiary Service Companics, 17 C.F.R. $\$ 256$ (1964); Uniform System of Accounts for Public Utility Holding Companies, 17 C.F.R. $\$ 257$ (1964); SEC Rule 27,17 C.F.R. $\$ 250.27$ (1964), with respect to classification of accounts for certain public utility companies.

${ }^{13}$ SEC Rules 17a-3 to $-5,-7$, I7 C.F.R. $\$ 240 . x 7 a-3$ to $-5,-7$ (1964).

${ }^{14}$ SEC Rules $3 \mathrm{Ta}-1$ to $-3,17$ C.F.R. $\$ \$ 270.31 \mathrm{ra}-1$ to -3 (1964).
} 
$1940^{15}$ governing the books and records to be maintained by investment advisers; ${ }^{10}$ and has adopted rules, embodied in a single over-all regulation designated as Regulation S-X, that state the requirements applicable to the form and content of financial statements required to be filed in registration statements and supplemental and periodic reports under the Securities Act, the Securities Exchange Act, the Holding Company Act, and the Investment Company Act. ${ }^{17}$ The SEC's regulations also incorporate the Commission's Accounting Series Releases, ${ }^{18}$ of which I02 have been issued to date and which are discussed below.

II

\section{SEC Accounting Series Releases As an Aid in the Development of Accounting Principles}

\section{A. Early Commission Experience with Accounting Principles}

The several federal securities laws were a direct result of generally inadequate disclosure on the part of securities issuers and numerous instances of outright misrepresentation. Another result of the unfortunate history of the Ig20s was that an increasing number of businessmen and accountants came to recognize the need for providing stockholders and potential investors with adequate financial data. Contemporary commentators dwelt on the gross inadequacies of financial reporting. Typical of their views was the following:

Not all, but at least some, of the terrific financial wreckage of the past three years could have been halted short of the bankruptcy courts by the adoption of fearless accounting methods. ... I I hope these disastrous experiences may hasten the time when, at least as to those corporations whose securities are held by the general public, the accountant's work will be done primarily for the shareholders and creditors at the corporation's expense, and not for the purpose of making as favorable a report on behalf of the management as the facts can be made to justify through carefully prepared "hedge clauses" in the auditor's certificate, which, while perhaps absolving him from legal liability, constitutes business immorality, if not actual dishonesty. ${ }^{10}$

The question of whether the observance of sound accounting principles or good accounting practice required not merely full disclosure but also fair disclosure had some interesting early history. In connection with a registration statement filed under the Securities Act in October 1934 by Northern States Power Company, it was disclosed that a subsidiary of the registrant had written up its net property account

\footnotetext{
${ }^{15} 54$ Stat. 847 , as amended, I5 U.S.C. $\$ \$ 80 \mathrm{ob}-1$ to -21 (1964).

${ }^{10}$ SEC Rule 204-2, I7 C.F.R. $\$ 275.204^{-2}$ (1964).

${ }^{17}$ SEC Reg. S-X, I7 C.F.R. \$2xo (1964, Supp. I965).

${ }^{18}$ See I7 C.F.R. $\$ 211$ ( 1964$)$.

${ }^{10}$ Lewis, Some Legal and Accounting Questions Presented by the Michigan General Corporation Act, 8 Accounting Rev. I45, I54 (I933). See also Eaton, Accountants and the New Social Order, I3 C.P.A. 460, 462 (I933); Paton, Shortcomings of Present-Day Financial Statements, 57 J. Accountancy 108 (I934).
} 
on the basis of an appraisal by more than eight million dollars and that the registrant's investment account was likewise increased by the same amount. These writeups had occurred some ten years previously, in 1924, and in that year as well as in the following year, 1925 , the registrant had charged unamortized debt discount and expense to capital surplus in the full amount of the appraisal write-up, thereby relieving the income account prior to registration. ${ }^{20}$ The registrant's accountant took exception to this accounting treatment in a revised certificate accompanying an amendment that explained in a footnote the effect of the accounting.

The full Commission disapproved of the accounting ${ }^{21}$ but, with two of the five commissioners dissenting, permitted the registration statement to become effective in this amended form. ${ }^{22}$ The majority was of the view that there had been adequate disclosure of the relevant facts in the amendment filed by the registrant and that it might not be entirely fair to proceed against the registrant since the Commission had not promulgated any accounting rules or regulations on the subject. The minority, however, was of the view that adequate disclosure and treatment required that the financial statements of the registrant be restated and that the company's past accounting practices be fully explained. ${ }^{23}$

\section{B. Accounting Sẻries Releases Through 1945}

It was essentially as the result of the Commission's experience with cases such as the Northern States case and of the generally vague concepts prevalent among practicing accountants as to what constituted sound accounting principles or good accounting practice that the Commission first undertook the issuance of its Accounting Series Releases. The first such release, issued on April I, 1937, understandably dealt with the accounting treatment of losses resulting from a revaluation of assets. ${ }^{24}$ In that release, the Commission announced "a program for the publication, from time to time, of opinions on accounting principles for the purpose of contributing to the development of uniform standards and practice in major accounting questions." As the first of these interpretations, the Commission published a letter sent by its then Chief Accountant to a registrant expressing the view that capital surplus should under no circumstances be used to write off losses that, if currently recognized, would have been chargeable against income.

On April 25, 1938, the Commission issued, as Accounting Series Release No. 4, the following statement of its "administrative policy with respect to financial statements":

\footnotetext{
${ }^{20}$ See Healy, The Next Step in Accounting, 13 Accountrive Rev. 1, 2-3 (1938).

${ }^{21}$ See id, at 3 .

22 Northern States Power Co., SEC Securities Release No. 254, Nov. 21, r934.

${ }^{23}$ Ibid. See also Healy, stspra note 20 , at $3-5$, for a discussion of this case and of additional carly cases producing similarly divided views of the Commission.

${ }^{24}$ SEC Accounting Ser. Release No. I, April I, 1937. In this release, the Commission also stated that a published interpretation that the Commission had issued a short time before (SEC Securitics Act Release No. 1210, Jan. 6, 1937), relating to the treatment of federal income and excess profits taxes and surtax on undistributed profits, should be considered part of the Accounting Series Releases.
} 
In cases where financial statements filed with this Commission pursuant to its rules and regulations under the Securities Act of 1933 or the Securities Exchange Act of 1934 are prepared in accordance with accounting principles for which there is no substantial authoritative support, such financial statements will be presumed to be misleading or inaccurate despite disclosures contained in the certificate of the accountant or in footnotes to the statements provided the matters involved are material. In cases where there is a difference of opinion between the Commission and the registrant as to the proper principles of accounting to be followed, disclosure will be accepted in lieu of correction of the financial statements themselves only if the points involved are such that there is substantial authoritative support for the practices followed by the registrant and the position of the Commission has not previously been expressed in rules, regulations, or other official releases of the Commission, including the published opinions of its chief accountant.

The phrase "substantial authoritative support," which appears twice in the abovequoted release, has not, so far as this writer is aware, ever been interpreted by the Commission. ${ }^{25}$ The Commission, however, has held that, "while the opinions of qualified expert accountants may be helpful, this Commission must in the last analysis weigh the value of expert testimony against its own judgment of what is sound accounting practice."26

The Commission's early releases indicated an intention to give weight to the practices of the accounting profession, but they also suggested that the Commission contemplated an active role for itself in the formulation, elaboration, and revision of principles with an eye to achieving more than mere disclosure of financial facts. For a number of years following these early policy statements, the Commission assumed a more direct role in accounting matters through issuance of Accounting Series Releases than it has in recent years. If one were to identify the turning point between what might be regarded as the Commission's early, more tutorial role and its later, less tutorial role in the development of sound accounting principles, one would probably select a date around the end of 1945 . Prior to that time, some fiftythree Accounting Series Releases had been issued, and the Commission had adopted Regulation S-X governing the form and content of financial statements required to be filed in registration statements and supplemental or periodic reports under the Securities Act and the Securities Exchange Act. ${ }^{27}$

so The phrase is one of a substantial number of items currently receiving the attention of the Accounting Principles Board of the American Institute of Certified Public Accountants. See Spectal Comm. on Opinions of the Accounting Principles BoArd, AICPA, Report I5 (1965). For suggested sources of "substantial authoritative support," see PAul Grady, Inventory of Generally Accepted Accounting Principles for Business Enterprises 52-53 (AICPA Accounting Research Study No. 7, 1965); Louis H. Rappaport, SEC Accounting Practice and Procedure 2.7-8 (2d ed. 1963).

${ }_{20}^{20}$ SEC Accounting Ser. Release No. 73, Oct. 30, 1952 (footnote omitted). See Interstate Hosiery Mills, Inc., 4 S.E.C. 706, $7 \times 5$ (1939).

${ }^{37}$ Regulation S-X was originally announced in SEC Accounting Ser. Release No. I2, Feb. 21 , I940. As subsequently modified and amended, Regulation S-X, I7 C.F.R. §210 (I964, Supp. I965), also applies to financial statements required to be filed in registration statements and annual reports under the Holding Company Act and the Investment Company Act. See SEC Accounting Ser. Releases Nos. 24, May 23, 1941; 29, Jan. 9, 1942; 33, April 28, 1942; 57, Nov. 27, 1946; and 72, March 12, r951. 
Between the dates of adoption of Accounting Series Release No. 4 on April 25, 1938, and Release No. 53 on November 16, 1945, releases issued dealt with such things as the disposition of existing unamortized bond discount and expense in connection with retirement of the related debt with proceeds from the sale of capital stock $;^{2 s}$ quasi-reorganizations; $;^{29}$ the treatment of premiums paid upon the redemption of preferred stocks; ${ }^{30}$ and the writing down of goodwill by means of charges to capital surplus. ${ }^{31}$ Other releases in the series up to the end of 1945 related to the adoption and amendment of Regulation S-X, auditing standards, the criteria of accountants' independence, and disciplinary proceedings against accountants. A large proportion of the releases dealt with specific questions of accounting principles that the accounting profession as a whole was not in a position to settle effectively.

Explanations for the relatively greater volume of Accounting Series Releases in the years prior to 1946 are several. In those years there existed a much greater diversity of opinion among accountants, registrants, and regulatory agencies as to sound accounting principles and the purpose and requirements of the securities laws. Nioreover, the Commission was faced with the urgent necessity, under the mandate of the Public Utility Holding Company Act, to simplify the huge and complex utility empires that had grown up. The accounting problems attendant upon the reorganization of holding companies were many and serious, and it is therefore not surprising that many of the Accounting Series Releases, particularly up to the end of 1945, had particular impact on public utility systems.

In addition to problems created by reorganization of holding companies, the Commission's early releases dealt with other current issues raised first by the depression and later by wartime. The rapidity of business developments in the years I937-45 undoubtedly goes far to explain the Commission's activity in issuing accounting releases. Nevertheless, the Commission seems also to have demonstrated in this period a greater willingness to take direct action in the formulation of sound accounting principles than it has displayed in recent years. Certainly the Commission's early pronouncements and its methods of resolving the accounting issues it faced during this period revealed to a considerable degree a commitment actively to promote the development of sound accounting principles irrespective of whether other accounting principles or practices had gained general acceptance with business and the accounting profession.

\section{Post-r945 Accounting Series Releases}

Since 1945, Accounting Series Releases have appeared less often, and they have been used only sparingly as a vehicle for presenting "opinions on accounting principles for the purpose of contributing to the development of uniform standards

\footnotetext{
${ }^{28}$ SEC Accounting Ser. Release No. ro, Dec. 23, 1938.

${ }^{20}$ SEC Accounting Ser. Releases Nos. 15, Mar. I6, 1940; 16, Mar. 16, 1940; and 25, May 29, 1941.

${ }^{30}$ SEC Accounting Ser. Release No. 45, June 2r, 1943.

${ }^{81}$ SEC Accounting Ser. Release No. 50, Jan. 20, 1945.
} 
and practice in major accounting questions." 32 Increasingly, releases have dealt with auditing standards, the independence of certifying accountants, disciplinary proceedings, amendments and revisions of Regulation S-X, and other matters not always involving questions of principle. The substantial reduction in the Commission's use of accounting releases in the area of accounting principles may be explained in part by the increasing consensus on accounting matters. However, a change in the Commission's conception of its and the accounting profession's relative roles in the formulation of accounting principles was probably also a factor. The Commission seems to have determined sometime in the late r940s, largely in response to urgings of the accounting profession, to give the profession an opportunity to undertake the formulation and dissemination of accounting principles. It was undoubtedly believed by the Commission that the Accounting Series Releases, Regulation S-X, and the experience in stop-order proceedings provided a meaningful foundation on which the profession could build. The Commission must have felt that it had by that time indicated the approach to accounting problems it preferred.

Among the more important post-1945 Accounting Series Releases in which accounting principles were at issue, either alone or in conjunction with the adequacy of the audit performed by the certifying accountant, are those treating the following matters: (I) the handling of the credit for deferred taxes in the balance sheet; ${ }^{33}$ (2) the acceptable alternatives for accounting for the investment credit; ${ }^{34}$ (3) the Commission's preference for an "all-inclusive" income statement over one reflecting only "current operating performance"; 35 (4) the disclosure to be made with respect to employee stock options; ${ }^{36}$ and (5) the balance-sheet classification, as current or noncurrent items, of installment receivables and the related deferred income taxes. ${ }^{37}$ Some specific comment on the Commission's rulings in these five areas is set forth below, both because of the interest and controversy aroused by the subject matter and because of the insight they give to the Commission's current attitude on accounting principles. Conclusions on the Commission's recent performance follow the discussion of particular issues it has faced.

\section{Releases Nos. 85 and 86: Deferred Taxes}

The issuance of Accounting Series Release No. 85 was preceded by a public notice of a proposed release on deferred tax accounting, ${ }^{38}$ the receipt of written views and comments, and two days of oral presentation before the Commission. As finally adopted, the release stated, in pertinent part, as follows:

\footnotetext{
${ }^{32}$ SEC Accounting Ser. Release No. I, April I, 1937.

${ }^{33}$ SEC Accounting Ser. Release Nos. 85, Feb. 29, 1960, and 86, April 12, 1960.

${ }^{31}$ SEC Accounting Ser. Release No. 96, Jan. ro, 1963.

${ }^{35}$ SEC Accounting Ser. Release No. 70, Dec. 20, 1950.

${ }^{30}$ SEC Accounting Ser. Release No. 76, Nov. 3, 1953.

${ }^{37}$ SEC Accounting Ser. Release No. 102, Dec. 7, 1965.

${ }^{88}$ SEC Securitics Act Release No. 40ro, Dec. 30, 1958.
} 
[A]ny financial statement filed with this Commission which designates as earned surplus (or its equivalent) or in any manner as a part of equity capital (even though accompanied by words of limitation such as "restricted" or "appropriated") the accumulated credit arising from accounting for reductions in income taxes resulting from deducting costs for income tax purposes at a more rapid rate than for financial statement purposes will be presumed by the Commission to be misleading or inaccurate despite disclosure contained in the certificate of the accountant or in footnotes to the statements, provided the amounts involved are material. ${ }^{39}$

In response to questions that had been raised in the proceedings with respect to the Commission's statutory authority to issue such a statement of policy, the Commission stated,

Under various statutes administered by it, the Commission has the authority and the corresponding responsibility to require that the financial statements filed with it be prepared in a manner which provides adequate and fair disclosure. This statement of policy is designed to advise all interested persons of the Commission's views as to the presentation in financial statements filed with the Commission of the credit arising when deferred tax accounting is employed. . . . It is not intended to direct or establish any system of accounts or to specify the manner in which a particular item shall be recorded on the books of the reporting companies, nor is it intended in any way to affect the requirements of any other governmental agency, federal or state, with respect to the manner in which such books of account shall be kept. ${ }^{40}$

The Commission noted that some accounting firms that appeared before the Commission at the oral presentation had urged that it was appropriate to designate as a part of earned surplus the credit arising from deferred tax accounting despite the contrary opinion of the Committee on Accounting Procedure of the American Institute of Certified Public Accountants (AICPA). ${ }^{41}$ The Commission stated its disagreement with the urgings of such accounting firms and added,

Moreover, the fact that there may be some authoritative support for different methods of classifying this deferred tax account does not preclude the Commission from determining for the future the manner in which the item should be classified in financial statements filed with it. In fact, as enunciated by the Commission in Accounting Series Release No. 4, dated April 25, 1938, the question of authoritative support is pertinent only where the position of the Commission has not previously been published in official releases. ${ }^{42}$

${ }^{30}$ SEC Accounting Ser. Release No. 85, Feb. 29, 1960.

${ }^{10}$ Ibid. (footnote omitted).

12 Letter from Committee on Accounting Procedure, AICPA, to Members of the AICPA, April 15, 1959, in AICPA, Accounting Resenrch and Terminozogy Bulletins (Final ed. 196r) [clarifying the Committee's position expressed in its bulletin Declining-Balance Depreciation (Accounting Rescarch Bull. No. 44 (revised), 1958)]. The Commission's statement of policy as to the balance-shect treatment of the accumulated credit was thus in accord with the position of the Committe on Accounting Procedure of the AICPA.

12 SEC Accounting Ser. Release No. 85, Feb. 29, 1960 (footnote omitted). 
Shortly after the issuance of Accounting Series Release No. 85, the AICPA "questioned whether the [Commission's] statement of policy had not covered the matter too broadly, indicating that there are some situations, notably intangible drilling costs, on which quite a few members of the Committee on Accounting Procedure of the Institute did not think it had yet spoken," although others were interpreting the Commission's release as being all-inclusive. ${ }^{43}$ To clarify the issue, the Commission issued a further release, consisting of a letter from its Chief Accountant to the Director of Research of the AICPA, advising him that the Commission had not intended "to make mandatory the use of deferred tax accounting beyond the requirements of generally accepted accounting principles." ${ }^{34}$

\section{Release No. 96: The Investment Credit}

That Accounting Series Release No. 4, issued in 1938 , is still the significant statement of the Commission's administrative policy on financial statements was reemphasized as recently as 1963 , when the Commission found it necessary to issue an accounting release ${ }^{45}$ expressing some views on the investment credit provided in the Revenue Act of $1962 .{ }^{46}$ The Commission noted, in that release, the extensive public discussion of the proper method of accounting for the investment credit and the fact that the Accounting Principles Board (successor since 1959 to the Committee on Accounting Procedure) of the AICPA had concluded that the investment credit should be reflected in income over the productive life of acquired property. ${ }^{47}$ The Commission stated, in response to inquiries it had received respecting the application of the Commission's accounting and disclosure requirements to this matter, that the policy expressed in Accounting Series Release No. 4 was "intended to support the development of accounting principles and methods of presentation . . but to leave the Commission free to obtain the information and disclosure contemplated by the securities laws and conformance with accounting principles which have gained general acceptance."

The Commission then stated that "in recognition of the substantial diversity of opinion which exists among responsible persons in the matter of accounting for the investment credit," it would accept with certain limitations either the complete deferral method endorsed by the Accounting Principles Board or the so-called 48-52 per cent method-i.e., crediting forty-eight per cent of the credit to income in the year in which the credit arose and reflecting fifty-two per cent in income over the productive life of the property ${ }^{48}-$ or, in the case of regulated industries, the too per

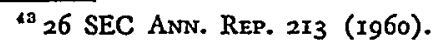

"SEC Accounting Ser. Release No. 86, April 12, r960.

${ }^{45}$ SEC Accounting Ser. Release No. 96, Jan. Io, 1963.

'0INT. Rev. Code of I954, $\$ \$ 38,46-48$, added by Revenue Act of $1962, \$ \S 2$ (a)-(b), 76 Stat. 962.

${ }^{47}$ Accounting Principles Board, AiCPA, Accounting for the "Investarent Credit" (Opinion No. 2, I962).

${ }^{48}$ It was INT. Rev. CODE of I954, $₫ 48(\mathrm{~g})$, that gave rise to the split accounting treatment favored
} 
cent flow-through method when authorized or required by regulatory authorities. The release also specified that the balance-sheet credit should not be made directly to the asset account and that income tax should not be stated in excess of the amount payable for the year. It included other comments regarding adequate disclosure, details of certain other accounts, and acceptance of appropriately qualified certificates where an alternative accounting treatment acceptable to the Commission was followed by the registrant. ${ }^{49}$

Subsequently, in the Revenue Act of 1964 , Congress repealed the requirement that the investment credit be treated for income-tax purposes as a reduction in the basis of the property to which the credit related. ${ }^{50}$ In March 1964, the Accounting Principles Board issued its Opinion No. 4 amending its Opinion No. 2.51 It noted that the Commission had issued Accounting Series Release No. 96 and, further, that the Commission had recently reconsidered and reaffirmed that position. The Board also observed that its own review of experience since the issuance of Opinion No. 2 showed that the investment credit had been treated by a significant number of companies as an increase in net income in the year in which the credit had arisen. The Board further stated that the Revenue Act of 1964 did not, in its view, change the essential nature of the investment credit and, hence, of itself afforded no basis for revising Opinion No. 2 as to the method of accounting for the investment credit. The Board then concluded that, since the authority of its opinions rested upon their general acceptability and since Opinion No. 2 had not attained sufficient acceptance to be effective, the alternative method of treating the credit as a reduction of federal income taxes in the year in which the credit arises would also be considered acceptable, although the Board still regarded the method recommended in Opinion No. 2 to be preferable. ${ }^{2}$

by the proponents of the so-called $48-52 \%$ method, since the amount of the investment credit was required to be applied against the depreciable base of the property. This, in turn, would have resulted in a pro tanto reduction, over the life of the property, of depreciation deductions for tax purposes. The deferral of $52 \%$ of the investment credit, therefore, was intended to offset the loss of depreciation deductions for tax purposes.

${ }^{40}$ The views of the Commission expressed in Accounting Ser. Release No. 96 thus differed from those of the Accounting Principles Board not only with respect to acceptable methods for reflecting the investment credit in income but also with respect to the balance-sheet treatment of any deferred portion of the investment credit. The Commission was express in its view that the credit (or any portion thereof) should not be made directly to the asset account that gave rise to the credit, whereas Opinion No. 2 of the Accounting Principles Board regards such crediting of the asset account as an appropriate method that "may be preferable in many cases." Accounting Principles BonRd, op. cit. supra note 47 , at 7 . The Board also recognizes treatment of the credit as a deferred income account in the balance sheet as equally appropriate.

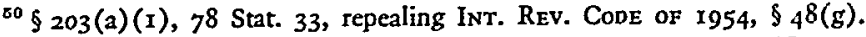

ac Accounting Principles Bosrd, AICPA, Accounting for the "Investment Credit" (Opinion No. $4, x 964)$.

${ }_{62}$ Id. at 22. An accounting commentator has stated that "a recent survey of practiccs for 1964 revcals that over $80 \%$ of 150 representative companies studied are following the [alternative] ... method of treating the investment credit as a reduction of federal income taxes in the year in which the credit arises." Savoie, The Accounting Principles Board, Financial Analysts Jour., May-June 1965, p. 53, at 56. 


\section{Release No. 70: The "All-Inclusive" Income Statement}

Another important post-I945 accounting release represented the culmination of a long-standing debate between certain members of the accounting profession and the Commission as to the relative merits of the "all-inclusive" versus the "current operating performance" concept of the income statement. ${ }^{53}$ Stated simply, the question was whether the income statement for a current year should include $(a)$ corrections of prior years' charges or credits and $(b)$ extraordinary or nonrecurring profits or losses not directly related to the company's ordinary business operations; or whether such items should be debited or credited directly to earned surplus. ${ }^{54}$

The staff of the Commission had made extensive studies of charges and credits to earned surplus, ${ }^{55}$ and the findings in such studies as to the disparate treatment in financial statements of many items of profit and loss buttressed the Commission's views in favor of the "all-inclusive" income statement. ${ }^{56}$ The Committee on Accounting Procedure of the American Institute of Accountants (AIA), as the AICPA was then known, in its Accounting Research Bulletin No. $32,{ }^{57}$ appeared to favor the "current operating performance" concept of the income statement, although it considered both methods of reporting acceptable. Concurrently with the issuance of Bulletin No. 32, the then Chief Accountant of the Commission addressed a letter to the Director of Research of the AIA, ${ }^{58}$ in which, after setting forth his reasons for disagreeing with certain aspects of the bulletin, he stated,

Under these circumstances the Commission has authorized the staff to take exception to financial statements which appear to be misleading, even though they reflect the application of Accounting Research Bulletin No. 32.

Concurrently, the staff of the Commission was engaged in a general revision of Regulation S-X. ${ }^{59}$ After exposing drafts of the proposed revision first to pro-

${ }^{53}$ SEC Accounting Ser. Release No. 70, Dec. 20, 1950, adopting Rules 5-03(a), 5-03(17), and 5-03 ( 18 ) under Article 5 of Regulation S-X. This action was said to effectuate a "long established policy of the Commission," which was "deemed necessary because of the not always consistent practice followed by some registrants of excluding certain items from the profit and loss or income statements with the result that the amount shown thereon as net income or loss has been susceptible to misinterpretation by investors." The Commission cited, with respect to its "long established policy," I4 SEC ANN. REP. III-I2 (1948), where its views advocating the "all-inclusive" as opposed to the "current operating performance" profit and loss or income statement had been expressed.

"It was assumed, of course, that the amounts involved would be material.

${ }^{\circ}$ Werntz \& King, An Analysis of Charges and Credits to Earned Surplus, 56 N.Y.C.P.A. 485 (1946).

${ }^{\text {co }}$ See II SEC ANN. Rep. 88 (1945); I2 SEC ANN. Rep. II7 (1946); I4 SEC ANn. Rep. III-I2 (1948).

${ }^{57}$ Income AND EARned Surplus (Accounting Rescarch Bull. No. 32, 1947), incorporated with modifications into Commitree on Accounting Procedure, AICPA, Restatement and Revision of Accounting Research Bulletins ch. 8 (Accounting Research Bull. No. 43, 1953) [hereinafter cited as Research BuLL. No. 43].

${ }^{58}$ Letter from Earle C. King to Carman G. Blough, Dec. II, 1947, in 85 J. Accountancy 25 (1948).

"One area of controversy that had existed for several years between the Commission and certain registrants and their accountants was resolved to the Commission's satisfaction while Regulation S-X was undergoing general revision. It had been the Commission's position that the earned surplus statement, rather than the profit and loss statement, should reflect the creation of any general-purpose con- 
fessional comment and later to general public comment, the Commission, in Accounting Series Release No. 70, made several changes in article 5 of Regulation $\mathrm{S}-\mathrm{X}$. These changes reflected the results of a compromise worked out between the staff of the Commission and representatives of the Executive Committee of the AIA after their appearance before the Commission. It is fair to state that Item 17 in the form of income statement, ${ }^{60}$ which provides for the addition or deduction of so-called special items of profit and loss following the caption "Net income or loss," has served as a nexus between the "all-inclusive" and the "current operating performance" points of view.

\section{Release No. 76: Employee Stock Options}

A further occasion for the use of an accounting release in the area of accounting principles arose in connection with the granting by corporations of stock options to executives and key employees. ${ }^{61}$ The Committee on Accounting Procedure of the AICPA, in its Accounting Research Bulletin No. $433^{62}$ had recommended disclosure in annual reports to stockholders of the status of options at the end of the year, including the number of shares under option, the option price, the number exercisable during the year, the number exercised during the year, and the option price of the shares acquired by exercise. ${ }^{63}$ The bulletin fixed the date of grant of the option as the relevant date for measuring the amount of the compensation to be charged to income. $^{\text {.4 }}$

In Accounting Series Release No. 76 , the Commission stated that it was adding Rule 3-2o(d) to Regulation S- $X^{65}$ because of the "apparent lack of unanimity of opinion among corporate and public accountants as to the appropriate manner" for measuring the amount of compensation to recipients of stock options to be charged to income. In view of the persuasive arguments which it stated had been received

\footnotetext{
tingency reserves and reserves designated for special purposes such as possible future declines in inventories and replacement of plant assets in periods of higher price levels. In October 1948, the AIA's Committee on Accounting Procedure, which had previously taken an equivocal position on such items in several research bulletins, adopted Accounting Research Bulletin No. 35, entitled "Prescntation of Income and Earned Surplus," withdrawing the option objected to by the Commission. See I5 SEC ANN. REP. I78-79 (I949).

${ }^{0}$ Rule 5-03(I7), I7 C.F.R. $\$ 210.5-03\left(I_{7}\right)\left(x_{964}\right)$.

${ }^{1}$ SEC Accounting Ser. Release No. 76, Nov. 3, 1953.

02 Research Bull. No. 43, ch. I3, $\$$ B.

os The New York Stock Exchange requires disclosure of the status of options at the beginning and end of the year as to the number of shares and prices and changes during the year. The Exchange does not express any preference as to accounting procedurc. See NEW YORx STOCK Exchange, CoMpANY Manunt (loose-leaf) A-Izo.

as Comamtee on Accounting Procedure, AIA, Accounting for Compensation in the Foras of Srock Optrons (Accounting Research Bull. No. 37, 1948), had fixed the date the option right became the property of the grantee (generally the date when he could first exercise the option) as the relevant date for measuring compensation. The Commission had at the time agreed with that bulletin, but application of that date to financial statements in a registration statement produced abnormal results, which resulted in revision of that bulletin. See Research BuLl. No. 43, ch. 13, \$ B, 919-1 See also Barr \& Koch, Accounting and the S.E.C., 28 Geo. WAsr. L. Rev. 176, 185 (1959).

${ }^{\text {OF }}$ I7 C.F.R. $\$ 210.03-20$ (d) (1964).
} 
for each of three dates-i.e., when the options were (I) granted, (2) exercisable, or (3) exercised-the Commission concluded that it would be inappropriate to prescribe a procedure for determining the amount of cost, if any, of stock options to be reflected in profit and loss or income statements. The Commission's new Rule 3-20(d), therefore, called for significant data as to the stock option plan, the number of shares under option, the option price, the fair value, and the total dollar amount of optioned shares, each at the several dates, and a statement as to the basis of the accounting to be followed. The rule permits the required information to be summarized in an appropriate manner.

\section{Release No. r02: Deferred Taxes on Installment Sales}

On October 4, 1965 , a national firm of certified public accountants petitioned the Commission to issue an Accounting Series Release relating to the balance-sheet classification of deferred income taxes arising from the use of the installment method of reporting gross profit for income-tax purposes so that such classification would be consistent with the classification of the related accounts receivable. ${ }^{66}$ The petitioner asserted that the general practice of registrants is to include the installment receivables in current assets but that many of them classify the related deferred income taxes as a noncurrent liability. Some registrants, it noted, were following a consistent current-asset and current-liability approach, but a number of such registrants were planning to reclassify the deferred-tax credit to a noncurrent-liability category. Asserting that the classification of the deferred taxes, where material, has a significant effect on the determination of a company's working capital and the credit ratings that it receives, and that the lack of comparability in the financial statements of many registrants could not be justified on the basis of different circumstances, the petitioner noted that independent public accountants were giving opinions that both the consistent and the inconsistent methods of classification were in conformity with "generally accepted accounting principles."

The petitioner also noted that in an Exposure Draft published by the Accounting Principles Board of the AICPA, in July $x 965$, of its then proposed Opinion No. 6, one of the proposed revisions that had been approved by the Board for inclusion in the Exposure Draft stated that deferred income taxes "should be classified as a current liability in the balance sheet to the extent that they are related to current assets which give rise to the tax deferment." ${ }^{\prime \prime 7}$ As pointed out in the petition, however, the subsequent definitive draft of the Board's Opinion No. $6^{67 a}$ had deleted the foregoing proposed requirement. The petitioner then requested that, since the accounting profession and the AICPA through the efforts of the Accounting

\footnotetext{
${ }^{00}$ SEC File No. S7-286-r, Petition of Arthur Andersen \& Co.

${ }^{67}$ Accounting Principles Board, AICPA, Status of Accounting Research Bulletins I 33 (Exposure Draft of Opinion No. 6, July 1965), reprinted in J. Accountancy, Aug. 1965, p. 57, at 58.

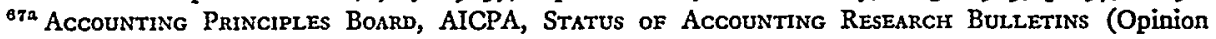
No. 6, 1965).
} 
Principles Board had not been able to resolve the problem on a timely basis, the Commission should issue an accounting release that would require consistent classification (as current or noncurrent) of the installment receivables and the related deferred taxes. The petitioner suggested that such release should approve balancesheet presentations under which ( $x$ ) the deferred income taxes on installment sales would be classified as a current liability if the related receivables are classified as a current asset, or (2) the installment receivables to be collected after one year would be classified as a noncurrent asset, or (3) the deferred taxes would be shown as a deduction from the related installment receivables.

After considering the petition and studying the various methods of classification employed by many registrants, the Commission issued an Accounting Series Release, applicable to financial statements filed with the Commission for fiscal years ending on or after December 31, $1965 .{ }^{67 \mathrm{~b}}$ In the release, the Commission noted that the majority of companies having installment receivables classified as current assets classified the related deferred income taxes as a noncurrent credit item, while some classified the deferred taxes as a current liability or as a deduction from the receivables. The Commission also referred to the apparent intention of certain registrants, at the end of their then current fiscal years, to change from current to noncurrent the classification of the deferred income taxes if other companies continued to classify such deferred taxes as a noncurrent item. The Commission expressed the view that the installment receivables and the related deferred income taxes pertaining to the same operating cycle clearly are both either current or noncurrent and that there is no justification from the standpoint of either proper accounting or fair financial reporting for the use of the operating-cycle approach for installment receivables and not for the related deferred income taxes.

Citing its prior Accounting Series Releases Nos. 4 and 96, the Commission then declared that, where installment receivables are classified as current assets in accordance with the operating-cycle practice, the related liabilities or credit items maturing or expiring in the time period of the operating cycle, including the deferred income taxes on installment sales, should be classified as current liabilities. It further declared that installment receivables not realizable within one year and the related deferred income taxes may be classified consistently as noncurrent items; and that assets and liabilities entering into the operating cycle shall be classified consistently as current or noncurrent items. The Commission stated, however, that it did not approve of one of the three suggested methods of classifying the deferred income taxes-namely, deduction of the deferred taxes from the related installment receivables.

\footnotetext{
${ }^{\text {C2b }}$ SEC Accounting Ser. Release No. I02, Dec. 7, I965.
} 


\section{Conclusions on the Commission's Post-1945 Releases}

The conclusion seems warranted that, in the more controversial areas of accounting principles, the Commission has indicated a greater readiness in the post-1945 period than in the prior period to accept alternative methods of accounting in financial statements. Possibly this may be attributable to the different types of accounting problems arising during the two periods. Whatever the reason, the tendency indicated in the post-I945 period seems to bespeak a caution, indeed a reluctance, on the part of the Commission to make categorical pronouncements on accounting principles in areas where the accounting profession is sharply divided.

The Commission's handling of the five specific issues discussed above demonstrates the extent of its reluctance in recent years to second-guess the sincerely held views of reputable accountants on questions open to doubt. With respect to deferred tax accounting, the Commission made clear its nonintention to make such accounting mandatory in situations where deferred tax accounting had not yet gained general acceptance. As for the investment credit, however, what the Commission really seemed to be saying was that it should not endorse the method of complete deferral of the credit, favored by the AICPA, to the exclusion of another method-partial deferral and partial flow-through-which had at least as much rational basis as the former. In the circumstances, therefore, the Commission deemed it appropriate to state its acceptance of either method.

With respect to the issue of the form of the income statement, while one might view the prescribed method of presentation of special items of profit and loss (Rule 5-03 (I7) of Regulation S-X) as an effort to obtain the best of two possible worlds, the method does, nevertheless, provide the investor with the necessary financial information and does disclose, conspicuously, information that he might otherwise fail to note if the particular item were buried in the surplus statement. As to stock options, the Commission's approach was one that called for disclosure in footnotes of the relevant facts rather than prescribing one single method of accounting, although it would seeem such a prescription might well have been of greater advantage to investors than the optional use of any one of a variety of methods of accounting consistently applied. Finally, while the Commission did deal forcefully with the question of the balance-sheet classification of installment receivables and the related deferred income taxes, in an area where the Accounting Principles Board of the AICPA, only shortly prior thereto, had determined not to require consistent classification of the receivables and the related deferred taxes, the Commission's action was taken only after a petition was filed with it by a national accounting firm requesting the Commission to resolve the problem by the means of an Accounting Series Release. 
III

\section{Formal SEC Proceedings Involving Accounting Principles}

Many of the Commission's most important formal proceedings involving accounting matters occurred during the first few years of its existence and, not surprisingly, dealt principally with the problems of asset valuation and accounting for stockholders' equity. While not limited to newly formed or promotional companies, they were most frequently concerned with such companies, which customarily issued large amounts of stock for assets having at best a nominal value. The Commission's concern with such accounting problems, expressed in findings and opinions issued, for the most part, pursuant to stop-order proceedings instituted by the Commission under section 8 (d) of the Securities Act, prevented many such corporations from selling their securities to the public. The Commission, of course, continues to use this type of proceeding wherever it deems it appropriate.

The Commission has held financial statements to be false and misleading in a variety of circumstances: Where property was acquired for stock, the acquired assets were not permitted to be recorded on the basis of the par value of the stock when shares of the same stock were being concurrently sold at prices significantly below par or when the stock was worth less than par. ${ }^{88}$ The cost of properties acquired may not include the par value of shares of stock nominally issued therefor and concurrently donated back to the company; ${ }^{60}$ nor may it include promotional services. ${ }^{70}$ Similarly, the balance sheet may not include as organization expense an amount of promoters' fees that is so grossly and unreasonably excessive as to be outside the range of reasonable difference of opinion as to the value of the promoters' services. ${ }^{71}$

\footnotetext{
${ }^{68}$ Automatic Tel. Dialer, Inc., ro S.E.C. 698 , 706 (194I); Poulin Mining Co., 8 S.E.C. Ir6, I2r (I940); Queensboro Gold Mines, Ltd., 2 S.E.C. 860, 862 (1937); Virginia City Gold Mining Co., 2 S.E.C. 855, 858 (1937); Canusa Gold Mines, Ltd., 2 S.E.C. 548, 557 (1937); National Boston Mont. Mines Corp., 2 S.E.C. 226, 25 I (I937); Yumuri Jute Mills Co., 2 S.E.C. 81, 86 (1937); Continental Distillers \& Importers Corp., I S.E.C. 54, 77-78 (r935); Unity Gold Corp., I S.E.C. 25, 33-34 (r934) (decided by FIC, which at that time was administering the Securities Act).

${ }^{60}$ Thomascolor, Inc., 27 S.E.C. 15I, I70-71 (1947); Automatic Tel. Dialer, Inc., 1o S.E.C. 698, 706 (I94I); Finger Canadian Lumber Co., 5 S.E.C. 543, 546 (1939); Thomas Bond, Inc., 5 S.E.C. 60,63 (r939); Virginia City Gold Mining Co., 2 S.E.C. 855, 858-59 (r937); Bering Straits Tin Mines, Inc, 2 S.E.C. 486, 495-96 (1937); Yumuri Jute Mills Co., 2 S.E.C. 8I, 86-87 (1937); Unity Gold Corp., 1 S.E.C. 25, 29-30 (I934). As a direct result of the Unity Gold case, the AIA adopted a rule prohibiting this accounting practice. Committee on Accounting Procedure, AIA, General Introduction and Rules Formerdy Adopted 6 (Accounting Research Bull. No. 1, I939). See Editorial, 58 J. Accountrancr $24 \mathrm{I}-44$ (I934); id. 40I, 407-08.

${ }^{20}$ Thomascolor, Inc., 27 S.E.C. X51, I69-70, I7I (I947); Automatic Tel. Dialer, Inc., Io S.E.C. 698, 706 (194r); Poulin Mining Co., 8 S.E.C. I16, I21 (1940); MacDonald Mines Ltd., 7 S.E.C. 223, 226 (1940) (by stipulation); Thomas Bond, Inc., 5 S.E.C. 60, 63-64 (1939); Platoro Gold Mines, Inc., 3 S.E.C. 872, 88I (1938); Paper Sales Co., 2 S.E.C. 748, 753-54 (I937); Rickard Ramore Gold Mines, Ltd., 2 S.E.C. 377, 390 (1937); National Boston Mont. Mines Corp., 2 S.E.C. 226, 250-51 (1937); Yumuri Jute Mills Co., 2 S.E.C. 8I, 86-87 (1937); Unity Gold Corp., I S.E.C. 25, 29-30 (1934).

${ }^{71}$ In Brandy-Wine Brewing Co., I S.E.C. I23, I35 (1935), the Commission stated, "Statutory provisions in the state of incorporation making values fixed by directors conclusive for certain purposes in the absence of fraud, cannot foreclose this Commission's inquiry as to the truthfulness of a statement
} 
Also held misleading was the recording of property at arbitrarily determined amounts that represented neither cost nor value arrived at by accepted methods. ${ }^{72}$ Properties held under lease, with option to purchase, were not permitted to be shown at the full value of the property or to be merged with properties owned in fee. ${ }^{73}$ Debt discount was not permitted to be included in the cost of assets purchased with the proceeds of the debt securities. ${ }^{74}$ Other problems dealt with in Commission decisions concerning accounting for property arose in the contexts of write-ups, appraisals, valuation of ore reserves, or acquisition of properties from promoters or other affiliated persons at prices determined without arm's-length bargaining. ${ }^{75}$

In cases involving improper valuation of assets acquired for stock, the Commission has consistently taken the position that disclosure in footnotes of the circumstances of the transaction is no substitute for proper accounting in the statements themselves. ${ }^{76}$ The grounds for refusal to accept footnote explanations is apparently that the statements are false and misleading and not simply that generally accepted accounting principles have not been followed. The Commission has stated that "a balance sheet item which is flatly untrue will not be rendered true merely by admission of untruth."

Improper methods of valuing inventories and determining cost of goods sold have

that a corporation has received services of a certain value, reasonably determined, nor prevent such a statement from being tested for truth under the standards set by the Securities Act."

${ }^{72}$ Thomas Bond, Inc., 5 S.E.C. 60, 64 (I939); Breeze Corporations, Inc., 3 S.E.C. 709, 7I7 (I938); Bering Straits Tin Mines, Inc., 2 S.E.C. 486,496 (1937).

${ }^{73}$ Finger Canadian Lumber Co., 5 S.E.C. 543 , 545-46 (1939); Canusa Gold Mines, Ltd., 2 S.E.C. 548,556 (I937); Franco Mining Corp., I S.E.C. 285,289 (I936).

"American Terminals \& Transit Co., I S.E.C. 7or, 7r2-15 (1936).

${ }^{75}$ Fall River Power Co., 38 S.E.C. $423,427-28$ (1958) (arbitrary valuations); Sans Souci Hotel, Inc., 37 S.E.C. III, II2 (I956) (write-ups); Associated Gas \& Elec. Co., II S.E.C. 975, I00I-04 (1942) (write-ups); Comstock-Dexter Mines, Inc., Io S.E.C. 358, 372-74 (I94I) (arbitrary ore valuation); Marquette Mines, Inc., 8 S.E.C. I72, I76-81 (1940) (arbitrary appraisal); Resources Corp. Int'l, 7 S.E.C. 689, 735-36 (1940) (acquisition of property from promoter); Petersen Engine Co., 2 S.E.C. 893, 907-08 (1937) (arbitrary appraisal); Emporia Gold Mines, Inc., 2 S.E.C. 209, 219-20 (I937) (same); Mining and Development Corp., x S.E.C. 786, 795-98 ( 1936 ) (arbitrary ore valuation); La Luz Mining Corp., I S.E.C. $217,221-23$ (I935) ("ludicrous" ore valuation); Haddam Distillers Corp., I S.E.C. $37,4 \mathrm{I}-46$ (1934) (arbitrary appraisal). See also Edsco Mfg. Co., 40 S.E.C. 865,867 (I96r) (acquisition of property from promoter).

In Associated Gas \& Elec. Co., supra, a proceeding instituted by the Commission pursuant to $\S 19$ (a)(2) of the Securities Exchange Act of 1934,48 Stat. 898 , I5 U.S.C. $\$ 78 \mathrm{~s}(2)$ (2) (1964), the Commission also severely criticized other accounting practices, e.g., write-offs of unamortized debt discount and expense to capital surplus, accruals of interest expense to capital surplus and to earned surplus or the omission of accruals altogether, and the excessive carrying amounts of investments in subsidiaries. II S.E.C. at ro24-45.

${ }^{70}$ E.g., F. G. Masquelette \& Co., SEC Accounting Ser. Release No. 68, July 5, r949, relating to the balance-sheet valuation of a leasehold without deduction of the discount resulting from the issuance in exchange therefor of common stock for a nominal consideration. An explanatory footnote was held insufficient to cure the defect. The Commission quoted from one of its early decisions, Queensboro Gold Mines, Ltd., 2 S.E.C. 860,862 (1937), where it had stated, "Nor is the mischief fully cured by an explanatory note revealing that the figure is 'purely arbitrary' and that the vendor, who purchased the property 'at a nominal cost' to himself, 'controlled the board who value'd the property. ... Such disclosure, while helpful, is not sufficient."

${ }^{77}$ Mining \& Development Corp., x S.E.C. 786, 799 (1936). 
also been condemned by the Commission, ${ }^{78}$ as has been the failure to disclose a substantial amount of financial information required by Regulation S-X.70 The presentation of interim financial statements on a basis different from that used in the full-year's certified statements, and the treatment of part of a contribution of capital by a principal stockholder as a reduction in losses by an adjustment of advertising expenses, were among the deficiencies cited by the Commission in one registration statement. $^{80}$ Also cited by the Commission as deficiencies were the failure to provide for unrealized but known losses, the inclusion in net sales of an amount which the registrant believed it was entitled to as additional compensation under a fixedprice contract that had been completed approximately two years earlier (with no claim for this amount, however, having ever been asserted), and the mingling of extraordinary, nonrecurring gains with ordinary operating income. ${ }^{80 a}$

In a proceeding under the Holding Company Act involving, inter alia, the inclusion of an accumulated credit for deferred income taxes in restricted earned surplus contrary to the Commission's Statement of Administrative Policy on deferred tax accounting, ${ }^{81}$ the Commission approved a settlement between the company and the Commission's staff whereby the caption of the accumulated credit was to be revised and the credit was not to be included as a part of either common stock equity or total capitalization, including surplus, for purposes of meeting specified debt and equity ratio tests. ${ }^{82}$

Inclusion of contingent payments made to the seller in the registrant's cost of assets acquired was held to be misleading on the ground that the contingent payments should have been shown as a deduction before arriving at net income. ${ }^{83}$

The Commission has also held that the declaration of a stock dividend by a company at a time when it did not have sufficient earned surplus against which to charge the stock dividend was "characteristic of manipulative schemes." 84

\footnotetext{
${ }^{78}$ Clinton Engines Corp., SEC Securities Act Release No. 4724, Sept. 28, r964; Precision Microwave Corp., SEC Securities Act Release No. 4694, May 22, 1964; Miami Window Corp., SEC Securities Act Release No. 4503, June 21, 1962; Industro Transistor Corp., 39 S.E.C. 287 , 289 (1959); Ultrasonic Corp., 37 S.E.C. 497, 501-03 (I957); Drayer-Hanson, Inc., 27 S.E.C. $838,855-59$ (I948).

${ }^{70}$ Strategic Minerals Corp. of America, 39 S.E.C. 798, 805 (1960); Hinsdale Raceway, Inc., 39 S.E.C. 419, 421-22 (1959).

${ }^{80}$ Hazel Bishop Inc., 40 S.E.C. 7I8, 722-25 (I96I).

${ }^{80 \pi}$ Cetron Electronic Corp., SEC Securities Act Release No. 4780, May 11, 1965.

si SEC Accounting Ser. Release No. 85, Feb. 29, 1960.

${ }^{82}$ Kentucky Power Co., CCH Fed. SEC. L. REP. (Transfer Binder, r957-6I) I 76742, at 80825-30 (SEC Holding Company Act Release No. 14353 , Jan. $13,196 r$ ).

${ }^{83}$ Faradyne Electronics Corp., 40 S.E.C. 1053, 1058-6I (1962).

84 Bruns, Nordeman \& Co., 40 S.E.C. 652, 657 (I96r). See also complaint filed on April 24, I961, in SEC v. Townsend Corp. of America, Civil No. 336-61, D.N.J., where, in the Fifth Count (paragraph $36(\mathrm{~g})$ ), the Commission alleged that financial statements filed with the Commission under the Investment Company Act and transmitted to stockholders were false and misleading in that certain stock issuances had been characterized in such financial statements as " $6 \%$ stock dividends," which "stock dividends" had been declared when the defendant corporation had no earned surplus. "The court enjoined the defendant corporation from inter alia, violating the relevant sections of that statutc. SEC v. Townsend Corp. of America, Civil No. 336-6r, D.N.J., May 3x, I96r, pt. I, II 2-3 and pt. II, If 4 .
} 
A particularly noteworthy case is the Commission's recent Atlantic Research decision, in which failure to include in the registrant's consolidated financial statements filed with the Commission financial statements of companies that were in fact subsidiaries of the registrant was held to render the registrant's financial statements inadequate and inaccurate. ${ }^{85}$

The Commission has also taken the position, in an advisory report under chapter $\mathrm{X}$ of the Bankruptcy Act, ${ }^{86}$ that the book value of assets of a debtor should not be revalued upward to reflect the excess of the total valuation found by the reorganization court over the existing book value of the debtor's assets. ${ }^{87}$

In summary, in the formal proceedings instituted by the Commission, where the Commission made findings of violation of generally accepted accounting principles, there was a further finding that the registrant's financial statements were false and misleading. The mere fact that there may have existed fairly widespread acceptance among registrants and their certifying accountants of a given accounting method or procedure did not deter the Commission from finding the related financial statements false and misleading and, in appropriate cases, from issuing a stop order. This writer is not aware of any subsequent change of position or attitude by the Commission with respect to violations of accounting principles previously condemned by it in a formal proceeding.

\section{The Nature of the Administrative Review Given Financial Statements}

An appreciation of the nature of the review given financial statements contained in registration statements and periodic reports filed with the Commission is aided by an understanding of the structure of the interested operating divisions and offices

\footnotetext{
${ }^{85}$ Atlantic Research Corp., CCH Fed. SEC. L. REp. (Transfer Binder, r96r-64) If 76949, at 81546-48 (SEC Securities Act Release No. 4647), Dec. 6, 1963 . The Commission had also previously temporarily suspended, pursuant to $\$ I 9$ (a)(4) of the Securities Exchange Act of 1934,48 Stat. 898, 15 U.S.C. $\$ 78 \mathrm{~s}(\mathrm{a})(4)\left(\mathrm{r}_{964}\right)$, trading in the registrant's stock because of serious questions as to the adequacy and accuracy of information available to the public concerning the financial condition of the registrant. In annual reports to stockholders, the registrant had reported profits on a parent-only basis, whereas in reports filed with the Commission covering the same periods financial statements on a consolidated, albeit not on a fully consolidated, basis had been presented.

It may be noted that on May 26, 1964, the Commission adopted an amendment to Rule I4a-3 under the Securities Exchange Act [I7 C.F.R. $\$ 240.14 a-3$ (Supp. x965)], requiring the inclusion of consolidated financial statements of the issuer and its subsidiaries in annual reports furnished to security holders in connection with the solicitation of proxies, if such consolidated financial statements are necessary to reflect adequately the financial position and results of operations of the issuer and its subsidiaries. Any material differences between the principles of consolidation or other accounting principles and practices, or methods of applying accounting principles or practices, applicable to financial statements filed with the Commission and those reflected in the report to security holders must be noted and the effect thereof reconciled or explained in such report.

${ }^{80}$ Chandler Act, 52 Stat. 883 (I938), as amended, II U.S.C. $\$ \$ 501-676$ ( 1964$)$.

${ }^{87}$ Yuba Consol. Indus., Inc., SEC Corporate Reorganization Release No. 229, May 3, 1965. SEC Accounting Ser. Release No. 25, May 29, x94r, appears clearly to contemplate that any revision in the book value of assets in connection with a quasi-reorganization will be solely by way of reduction rather than increase.
} 
of the Commission. Registration statements and periodic reports filed under the Securities Act and the Securities Exchange Act are examined by the Division of Corporation Finance, except that, with respect to investment companies registered under the Investment Company Act, registration statements filed under both the Securities Act and the Investment Company Act and periodic reports filed under both the Securities Exchange Act and the Investment Company Act are examined by the Division of Corporate Regulation. Periodic reports filed by registered holding companies under the Holding Company Act are also examined by the Division of Corporate Regulation. The Divisions of Corporation Finance and Corporate Regulation divide their workloads among several branches. Each branch, in turn, employs attorneys, financial analysts, an accountant, and secretarial and clerical personnel. The accountant is an individual of professional stature whose duties include the examination of the financial statements submitted by a registrant to determine, in so far as possible, whether they meet the requirements of the Commission and have been prepared in accordance with generally accepted accounting principles based in most cases on an audit certificate in accordance with generally accepted auditing standards.

On the basis of its examination of the filing, the staff prepares a memorandum of deficiencies, which is reviewed, as to accounting matters, by the chief accountant of the Division of Corporation Finance or his staff or by an appropriate officer of the Division of Corporate Regulation, who is also a professionally trained accountant. Any novel or especially important questions of accounting policy or principle, or of auditing standards, which are raised by the branch accountant or by the accounting supervisor are reviewed by the Chief Accountant of the Commission before being incorporated into a letter of comments to be forwarded to the registrant. These letters of comments, and the correspondence or conferences with registrants and their accounting representatives resulting therefrom, have provided a useful means of resolving, with reasonable promptness, accounting and auditing questions that might otherwise have to be settled through extended, formal hearings. Failure on the part of the staff to cite a deficiency in the financial statements should not be mistakenly construed as necessarily indicating agreement by the staff as to the propriety of the financial statements.

The Commission's staff frequently utilizes pre-filing correspondence or conferences with the registrant and its accounting representatives as a means of obviating the need for citing deficiencies in a letter of comments. Similarly, at the request of the registrant or its accountants, the staff is available to discuss the applicability of existing accounting principles to a special factual situation or to advise with respect to cases where a particular accounting principle is known to be undergoing reconsideration. Where particularly difficult or novel questions arise that cannot be settled by the accounting staff of the divisions and by the Chief Accountant, they are referred to the Commission for consideration and decision. 
With specific reference to a registration statement, the accountant necessarily reads the entire document to familiarize himself with the general operations and history of the registrant. In appropriate situations, he may refer to articles in newspapers or financial publications, or to stockholder reports, for relevant information. In examining the financial statements, he has in mind particularly the requirements of Regulation S-X, compliance with the requirements of the form prescribed for the registration statement or periodic report, the Commission's Accounting Series Releases, Commission precedents in similar matters, and the various bulletins, opinions, and statements issued by committees or boards of the AICPA and the American Accounting Association.

The examining staff naturally accords considerable weight to the certification of a registrant's financial statements by an independent public accounting firm. Indeed, as the Commission pointed out in one of its Accounting Series Releases, the value of a review of a company's financial statements by independent accountants who are in no way connected with the business, was established even before the passage of the Securities Act. ${ }^{8 s}$ As noted previously, the Securities Act requires certification of the financial statements of a registrant by an independent accountant, and, with only certain exceptions, the Commission's rules under the other principal statutes administered by it require similar certification.

While certification of a registrant's financial statements is, of course, an important factor considered by the staff in its review of a filing made with the Commission, the Commission has indicated in its Accounting Series Releases Nos. 4 and 96 that it must retain the ultimate authority to determine the propriety of the financial statements filed by the registrant.

\section{V}

\section{The Commission's Position in the Current Controversy Over}

\section{Aiternative Accounting Principles}

No one can seriously doubt that the financial statements currently being transmitted to stockholders, creditors, and the investing public are immeasurably superior, as to form and content and fullness and fairness of disclosure, to what were considered the acceptable norms some thirty-odd years ago. Nevertheless, in the vast area of nonregulated enterprises, published financial statements, while certified as having been prepared in accordance with generally accepted accounting principles, frequently employ alternative methods of reporting for certain identical or generally similar types of transactions. This same situation also exists to a considerable extent in the regulated industries despite the existence of prescribed uniform systems of accounts. A partial list of items as to which alternative accounting practices exist would include valuation of inventories; depreciation and depletion; pension

\footnotetext{
${ }^{88}$ SEC Accounting Ser. Release No. 8I, Dec. II, I958.
} 
costs; business combinations; goodwill; research and development costs; the "allinclusive" versus the "current operating performance" profit-and-loss or income statement; allocation of income taxes; realization of income; and long-term leases. ${ }^{80}$

Critics of the existence of acceptable alternative principles of accounting have asserted that the financial results of operations of companies in the same industries are frequently not susceptible of meaningful, and indeed produce misleading, comparisons by the great body of public investors. ${ }^{00}$ They further argue that, while disclosure and consistency are desirable for reporting purposes, they are not a satisfactory substitute for more uniform accounting principles. ${ }^{01}$ Defenders of acceptable alternatives do not agree that there is such a diversity of accounting principles as to vitiate comparisons between one company and another, ${ }^{92}$ and assert that advances in the development and improvement of accounting principles "will come about not by building a Procrustean bed but by refinement of existing practices and seeking better ones." $\$$

Since 1937 and the promulgation of Accounting Series Release No. I, the Commission has actively encouraged the development of uniform standards and practice in major accounting questions. It has generally pursued the policy of working with and supporting the accounting profession in the development of accounting principles. $^{94}$ The staff of the Commission has continuing contact and consultation with representative professional accounting and financial-analyst organizations, with industry groups, and with other government agencies. In its 1965 annual report the Commission stated as follows with respect to the extent of the cooperation:

${ }^{89}$ For additional items, see Grady, op. cit. supra note 25, at 373-79. Grady's list is set forth in full in Appendix $D$ at the end of this symposium.

${ }^{\circ}$ E.g., Anreder, Pitfalls for the Unwary, Barron's, Dec. 24, 1962, p. 3i Hall, The Need for Uniform Accounting Standards, Mich. C.P.A., June 1963, p. 19, at 23; Hearings on H.R. 6789, H.R. 6793, and S. 1642 Before a Subcomm. of the Hoise Comm. on Interstate and Foreign Commerce, 88th Cong., Ist \& 2d Sess., pt. 2, at 756-59 (1963-1964) (statement of Leonard Spacek) [hereinafter cited as Hearings]; address by Leonard Spacek, Are Double Standards Good Enough for Investors but Unacceptable to the Securities Industry?, before the New York Soc'y of Security Analysts, New York City, Scpt. 30, 1964 , in Financial Analysts Jour., March-April 1965, p. 17, at 23-25; address by Leonard Spacek, Corporate Profits: Accounting Variations and Their Effect on Corporate Profits, before the ad Annual Conference on Basic Forces Affecting Equities, New York University, New York City, Fcb. 18, 1965, pp. 4, 5-6.

The bills considered in the Hearings culminated in the enactment of the Sccurities Acts Amendments of 1964,78 Stat. 565 (codified in scattered subsections of 15 U.S.C. $\$ 78$ ).

${ }^{11}$ Catlett, Controversy Over Uniformity of Accounting Principles, J. Accountancy, Dec. 1964, p. 37, at 39 .

${ }^{02}$ E.g., Grady, op. cit. supra note 25 , at $380-8 \mathrm{r}$; Fox, "Useful Comparability" in Financial Rcporting, J. Accountancy, Dec. 1964 , p. 44 , at 48 ; address by Thomas D. Flynn, Accounting Principles and Financial Analysts, before the New York Soc'y of Security Analysts, New York City, Jan. 27, 1965, in Financial Analysts Jour., March-April 1965, p. I6.

${ }^{98}$ Flynn, supra note 92, at 22.

os Hearings 1300,1305 (memorandum prepared by the Office of the Chief Accountant, SEC). Sec also address by SEC Commissioner Byron D. Woodside, Government-Industry Relations-Securities and Exchange Commission and Corporate Securities Regulation, before the $45^{\text {th }}$ Annual Conference of the National Ass'n of Accountants, Washington, D.C., June 23, I964, p. xo; Cohen, Current Developments at the SEC, 40 Accountrivg REv. 1, 6 (1965). 
Recognizing the importance of cooperation in the formulation of accounting principles and practices, adequate disclosure and auditing procedures which will best serve the interests of investors, the American Institute of Certified Public Accountants, the Financial Analysts Federation, and the Financial Executives Institute appoint committees which maintain liaison with the Commission's staff.

The Commission on its part authorized its Chief Accountant to continue to serve during the year as a member of an advisory committee to the Accounting Principles Board of the $\left[\right.$ AICPA] ... . ${ }^{85}$

In the lively controversy that has surrounded the existence of acceptable alternative accounting principles, ${ }^{96}$ suggestions have been made that, unless these differences are materially narrowed, presumably to the point of their elimination, the Commission, acting under the statutory powers granted to it under the several federal securities laws, may be compelled to step into the controversy and undertake to resolve and eliminate these differences. ${ }^{97}$ Replying to this comment, the then Chairman of the Commission, while agreeing that the Commission has the necessary power to "set the rules" on uniformity, stated that "Government should not be called upon to do everything, and actually we do not want to.... We are, therefore, not prepared to accept the mantle . . . cast over us." ${ }^{\text {"98 }}$ He further stated that management could help in preventing "the encroachment of Government by participating directly in steps toward agreement upon accounting principles."

The proposal has also been made to amend the Securities Act and the Securities Exchange Act to require the accounting and reporting practices followed in the preparation of financial statements of registrants to "be based on uniform accounting standards and principles as determined by the accounting profession" so as to enable the investor to make an informed investment decision and "to provide a basis for comparing [the registrant's] . . . security with others issued by companies in the same or different industries." 100 Under this approach, the Commission would be charged with "the responsibility of determining whether the accounting profession has taken appropriate action" to achieve such ends. ${ }^{101}$ In response to a question at the congressional hearings as to whether the Commission already had such a responsibility, the former Chairman answered in the affirmative, and added, "I trust we are exercising it."102 A further, fuller statement of the Commission's views on that proposal was presented in a statement prepared by the Office of the Chief Accountant, which stated, in pertinent part, as follows:

\footnotetext{
${ }^{85} 3$ I SEC ANN. REP. I 43 (I965).

${ }^{\circ 0}$ E.g., Flynn, Corporate Executives View Accounting Principles, J. Accountancy, June 1965, p. 3I; Phillippe, Top Management's Stake in Financial Reporting, J. Accountancy, Dec. 1963, p. 37; The Accounting Stalemate: Management's Move Now?, Dun's Rev., May 1965, p. 55.

${ }^{07}$ E.g., Anthony, Showdown on Accounting Principles, Harv. Bus. Rev., May-June 1963, p. 99, at I0I-02, $105-06$.

${ }^{\circ 8}$ Cary, The SEC and Acconnting, J. Accountancy, Dec. 1963, p. 47, at 49 .

oo Ibid.

${ }^{100}$ Hearings 760 (statement of Leonard Spacek).

101 Ibid.

${ }^{108}$ Hearings 1298 (testimony of William I. Cary).
} 
[T] he Commission has cooperated throughout the years of its existence with representatives of the American Institute of Certified Public Accountants, and others, in an endeavor to develop and promote better financial reporting, and a more general acceptance of sound accounting practices. Experience has borne out that the investor, and the public, are best served by this practice, and by the policy of requiring a certificate of independent accountants which expresses an opinion as to the overall fairness of the financial position and operating results reported upon, and the avoidance of prescribing detailed regulations as to accounting methods, practices, or principles. No legislative endorsement of this policy is considered necessary. ${ }^{103}$

The proposal made at the hearings was not adopted by Congress.

Some members of the Commission have spoken publicly on the issue of uniformity in accounting principles. One former member, while disclaiming any suggestion that unvarying application of uniform accounting principles was a desirable end in itself and asserting a dislike for "straitjackets," suggested that the Commission may not have gone as far as it should in the direction of exercising the "sweeping powers" given it under section 19 of the Securities Act. ${ }^{104}$ One present member of the Commission, stating that the Commission had the statutory authority to prescribe by rule how financial statements should be prepared and presented, pointed out that the Commission early in its life, at the request of the accounting profession, had stood aside and not only had withheld governmental action but had actively encouraged the full self-development of the initiative sought to be exercised by the profession. ${ }^{105} \mathrm{He}$ also expressed a preference for "some sacrifice of the ultimate in consistency and uniformity and acceptability" over a "rule-government or industry inspired-which either binds people to a rigid conformity or sets up a standard from which departures multiply in achieving solutions to problems." ${ }^{\text {"106 }}$

The present Chairman of the Commission has stated that the Commission is of the view that "an immediate and pressing objective is to eliminate the use of alternative accounting principles not justified by differing circumstances."107 One year later, in November 1965 , Chairman Cohen had the following statement to make to the same audience:

While some action has been taken by the accounting profession, the overall picture is not encouraging. In this area, as in so many others, the job will be done

\footnotetext{
${ }^{103}$ Hearings 1305 (memorandum prepared by the Office of the Chief Accountant, SEC).

104 Address by Jack M. Whitney II before the Washington Soc'y of Investment Analysts, Washington, D.C., Feb. 5, Ig63, pp. 6-7.

${ }^{106}$ Address by Byron D. Woodside, stipra note 94 , at ro.

${ }^{100}$ Ibid. See also the recent important address by Commissioner Woodside, A Revien of the Commission's Administrative Policies Relating to Financial Reporting under the Securities Acts, before the $4^{\text {th }}$ Annual Accounting Forum of Hayden, Stone Inc., N.Y.U. Graduate School, New York City, Nov. I8, 1965 .

${ }^{10 z}$ Address by Manuel F. Cohen before the Investment Bankers Ass'n of America, Hollywood, Fla., Dec. 1 , 1964, p. 12 .
} 
better, and compliance will be more willing and therefore more thorough, if the initiative is shared with, if not assumed by, the industry. We would rather have it that way, if you will let us. I say this despite the fact that we are now considering some limited action of our own in this area-action which is not designed to undermine the efforts of the leaders of the profession but rather to emphasize to the entire profession the urgency of immediate and effective support of those who are seeking sound procedures to obviate unjustified differences in the treatment and presentation of similar problems. ${ }^{107 a}$

This statement suggests both a concern over the pace of progress and a potential willingness on the part of the Commission to utilize its power to assist and encourage the accounting profession in its efforts. The "limited action" referred to by Chairman Cohen was apparently Accounting Series Release No. 102, which appeared one week later and is discussed at length above.

The AICPA, acting through its Accounting Principles Board, which was organized in 1959, has endeavored to narrow the areas of difference and inconsistency in practice. In October 1964 , the Council of the AICPA issued a special bulletin, applicable to financial statements for fiscal years beginning after December $3 \mathrm{r}$, 1965 , which would, inter alia, require disclosure in the accountant's report (unless disclosure was contained in a footnote to the financial statements) of any departure from an accounting principle accepted in an opinion of the Accounting Principles Board (including accounting research bulletins issued by the predecessor Committee on Accounting Procedure). ${ }^{108}$ Research studies are in progress under AICPA auspices on several important, controversial accounting problems, ${ }^{109}$ but it must be recognized that their completion will require time and that the resultant adoption of related opinions by the Accounting Principles Board will further extend the date when definitive action may be completed. To date, seventeen projects have been initiated for study, of which seven have resulted in published reports, one has been discontinued, and nine are pending. ${ }^{110}$

While the accounting profession should be supported in its efforts to promote uniformity in accounting principles, it seems fair to ask whether too much reliance is being placed by corporate managements, by the accounting profession at large, by the investing public-and by the Commission itself-on the professional accounting organizations. While such reliance has been the Commission's policy for at least twenty years, the efficacy of that policy, like that of any other long-standing policy, deserves periodic re-examination and reassessment. It would seem that now would be a most appropriate time for such a new appraisal.

\footnotetext{
${ }^{107 a}$ Address by Manuel F. Cohen before the Investment Bankers Ass'n of America, Hollywood, Fla., Nov. 30, r965, pp. I0-II.

${ }^{108}$ AICPA, Disclosure of Departures from Opinions of Accounting Principles Bonrd (Special Bull., I 964 ).

100 Special Comm. on Opinions of the Accounting Principles Bonrd, AlCPA, Report $37-38$ (1965).

${ }^{110}$ Ibid.
} 